\title{
Incidence of Insect Pest in Brinjal under Agro-Climatic Condition of Rewa District, Madhya Pradesh, India
}

\author{
Sachin Kumar Jaiswal, M.R. Dhingra, Akhilesh Kumar*, \\ Harishankar Bagchi and Umashankar Kaushik
}

Department of Entomology, JNKVV-College of Agriculture, Rewa-486 001, India

*Corresponding author

\section{A B S T R A C T}

\section{Keywords \\ Incidence, Solanum melongena, Insect-pests, Natural enemies \\ Article Info \\ Accepted: 06 May 2018 Available Online: 10 June 2018}

The study, done on the incidence of insect pest, revealed the presence of seven species of insect pests and three species of predator during the period of study from 16 September 2016 to 15 April 2017 at various stages of the brinjal crop after transplanting in district Rewa, Madhya Pradesh. The presence of whitefly, aphid, jassid and hadda beetle were recorded from the vegetative to maturity stage of the crop, while brinjal shoot and fruit borer as the most dominating species of the pest at vegetative as well as flowering and fruiting stage of the crop. The infestation of mealy bug and lace bug were recorded in the late season of the crop i.e. January to April 2017.

\section{Introduction}

The vegetables are an important dietary component, because of this reason its extensively cultivated in the world, including India. Amongst the various vegetables, Brinjal (Solanum melongena L; family- Solanaceae), commonly known as eggplant, is cultivated throughout the year in the country (Shukla and Khatri, 2010). Brinjal cultivation in the nation is done in about 680 thousand hectare area with an annual production of 12,706 thousand tonnes and productivity of 18.7 tonnes per hectare. In Madhya Pradesh, it is cultivated in 46.12 thousand hectare area with a productivity of 25.02 tonnes per hectare (Anonymous, 2015). Among the brinjal cultivating state in India; Orissa, Bihar, Karnataka, West Bengal, Andhra Pradesh, Maharashtra and Uttar Pradesh are the major brinjal growing states. West Bengal is the leading states contributing about $23 \%$ of the national production while Madhya Pradesh is contributing about only $8 \%$ (NHB, 2014).

Although, productivity of the brinjal in the state is higher than national productivity but quality production of the crop is a matter of concern as it is severely affected by various insect pest and diseases throughout the year. Among the insect pest jassid (Amrasca biguttula biguttula (Ishida), aphid (Aphis gossypii (Glover), whitefly (Bemisia tabaci (Gennadius), hadda beetle (Epilachna vigintioctopunctata), mealybug 
(Coccidohystrix insolita (Green), lace bug (Urentius sentis Distant) and shoot and fruit borer (Leucinodes orbonalis (Guenee) have been reported to cause considerable yield loss to the crop (Deole, 2015).

\section{Materials and Methods}

A field experiment was carried out at Entomology Instructional Farm, JNKVV, College of Agriculture Rewa (M.P.), during Kharif \& Rabi 2016-17. Popular Pusa Kranti, was sown in $128 \mathrm{sq}$. meter area following the standard package and practices of the crop. Observations on the incidence of different insect pests and natural enemies were recorded on 5 randomly selected plants from three locations of the experimental area. The observations were recorded on randomly selected plants of untreated plots once in a standard week. It is started after transplanting and continued up to the maturity of the crop. The crop was kept free from insecticide treatment.

\section{Results and Discussion}

The study pertaining to incidence of insect pest, indicated the presence of seven species of insect pests and three species of predators during the period of study from $16^{\text {th }}$ September 2016 to $15^{\text {th }}$ April 2017 at various stages of the brinjal crop after transplanting in district Rewa, Madhya Pradesh.

The insect pests recorded on the crop were whitefly, aphid, jassid and hadda beetle from vegetative growth stage to maturity of the crop, while brinjal shoot and fruit borer was noted, as the most dominating species of the pest, at vegetative as well as flowering and fruiting stage of the crop. The infestation of mealybug and lace bug were recorded in the late season of the crop i.e. from January to April 2017 (Plate 1-3).

Incidence of whitefly
Whitefly was recorded on the crop, 16 days after transplanting and

It remained active thereon upto second fortnight of March 2017.

\section{Incidence of jassid}

Jassid was observed on the crop when it was 27 days old after transplanting and remained thereon upto $30^{\text {th }}$ March 2017.

\section{Incidence of aphid}

Aphid was recorded on the crop from 35 DAT ( $21^{\text {st }}$ October) in high density and found active upto 175 DAT (i.e. $10^{\text {th }}$ March 2017).

\section{Incidence of hadda beetle}

Hadda beetle was recorded on the crop from 50 DAT $\left(5^{\text {th }}\right.$ November $)$ and found active upto $121^{\text {st }}$ DAT (i.e. $15^{\text {th }}$ January 2017).

\section{Mealybug}

Mealybug was recorded on the crop with its first incidence on $125^{\text {th }}$ DAT (19 ${ }^{\text {th }}$ January) and thereafter remained active upto $3^{\text {rd }}$ week of March.

\section{Lace bug}

Lace bug was observed on the crop at $183^{\text {rd }}$ days old transplanted plants remained active throughout the experimental period i.e. $14^{\text {th }}$ April 2017.

\section{Shoot and fruit borer}

Incidence of shoot and fruit borer was noted on the crop when it was 76 days old after transplanting i.e. vegetative stage of the crop and remained active upto $20^{\text {th }}$ March 2017. 
Plate.1 Incidence of insect pests in brinjal crop in Rewa district during Kharif \& Rabi 2016-2017

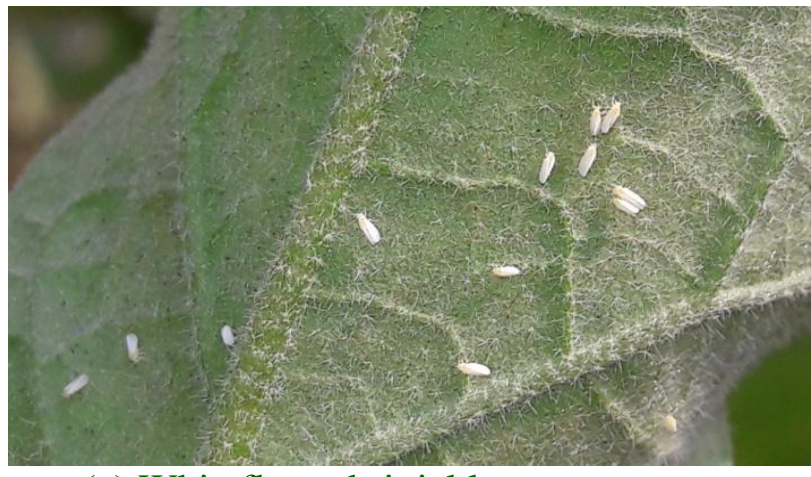

(a) Whitefly on brinjal leaves

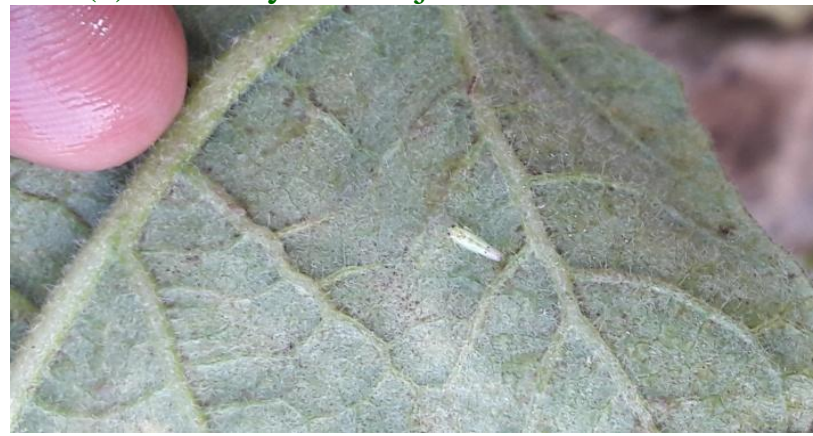

(c) Jassid on brinjal leaves

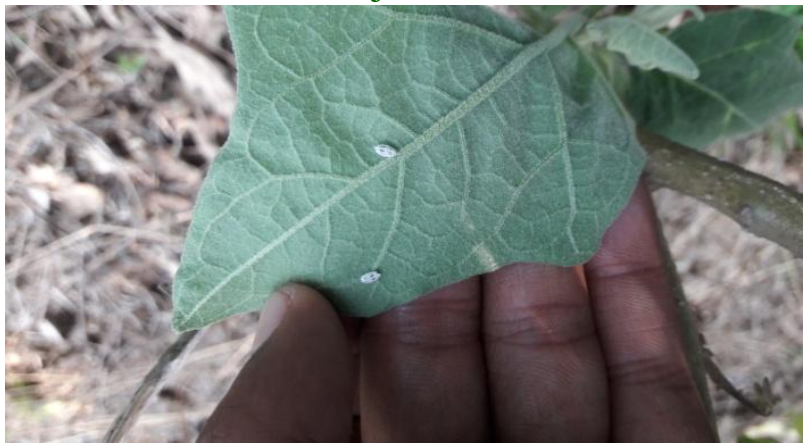

(e) Mealybug on brinjal leaves

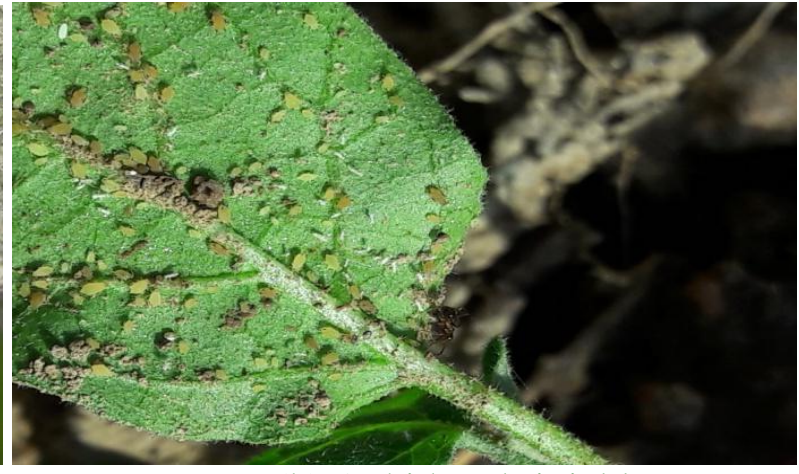

(b) Aphid on brinjal leaves

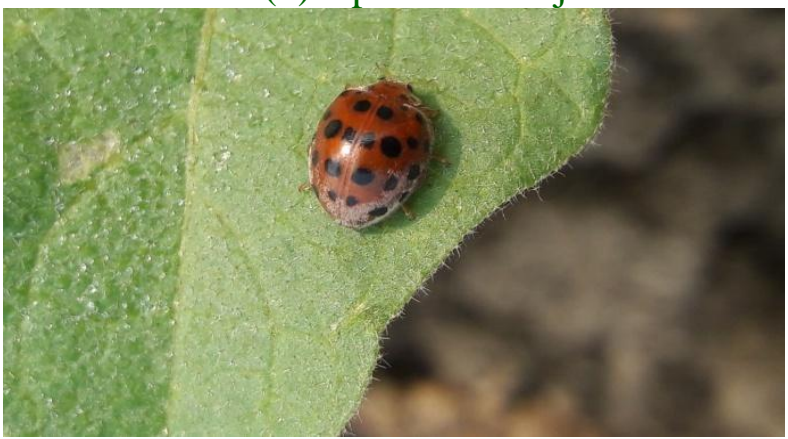

(d) Hadda beetle on brinjal leaves

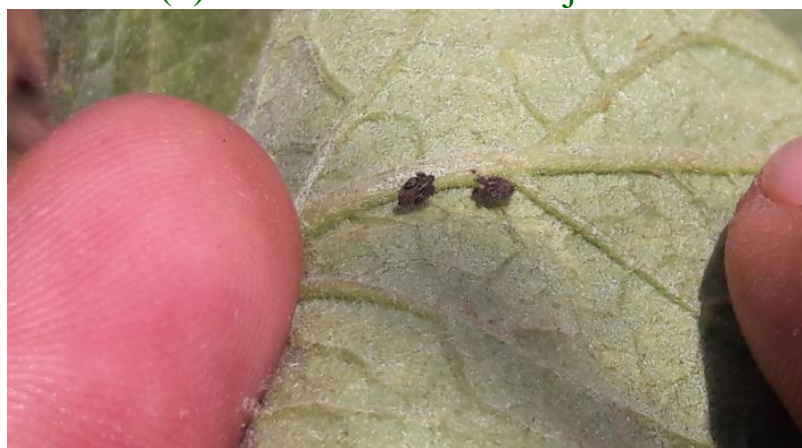

(f) Lace bug on brinjal leaves

Plate.2 Incidence natural enemies in brinjal crop in Rewa district during Kharif \& Rabi 20162017

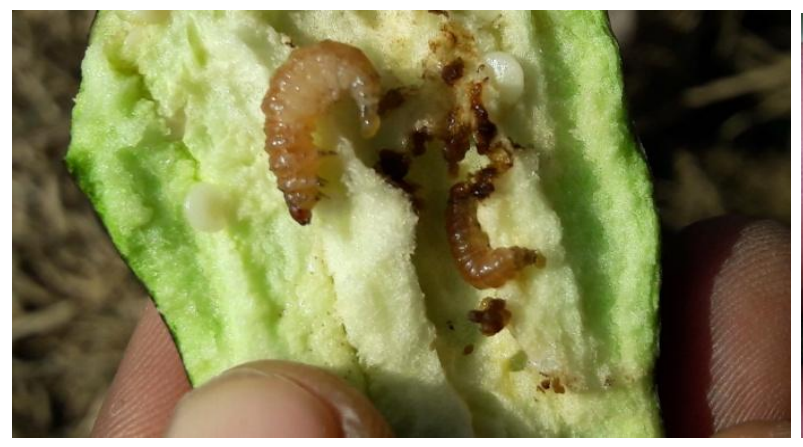

(a) BSFB larvae

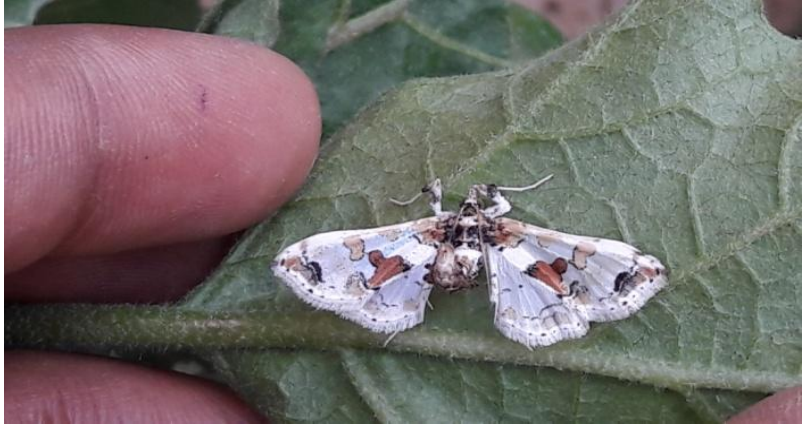

(b) BSFB adult 


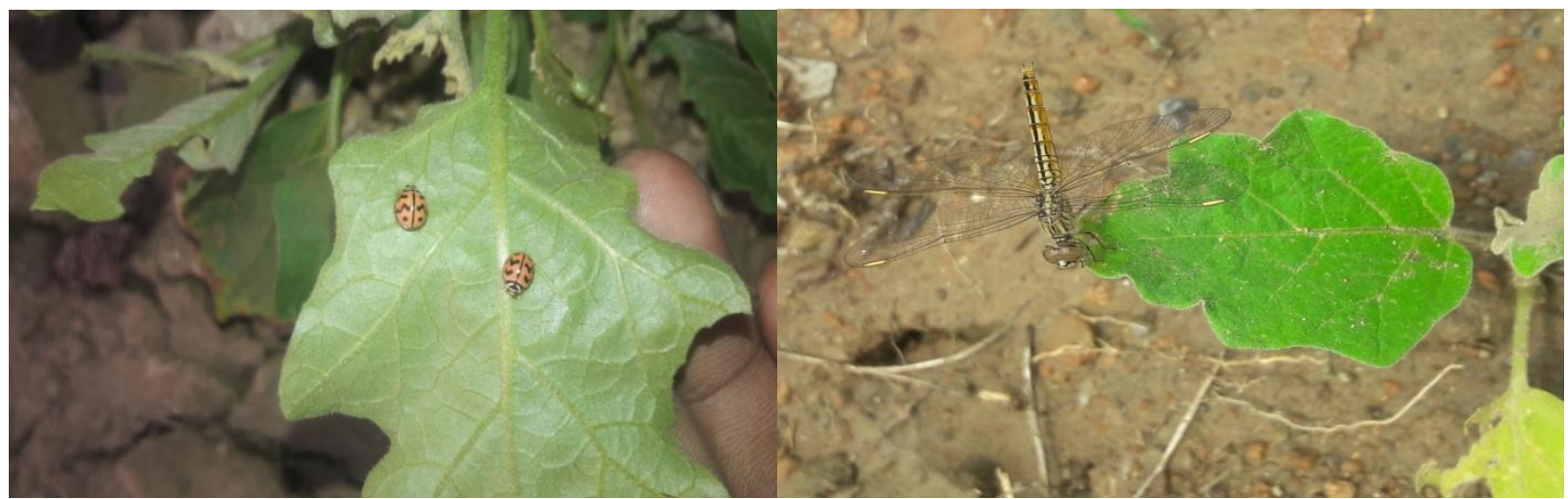

(c) Lady bird beetle

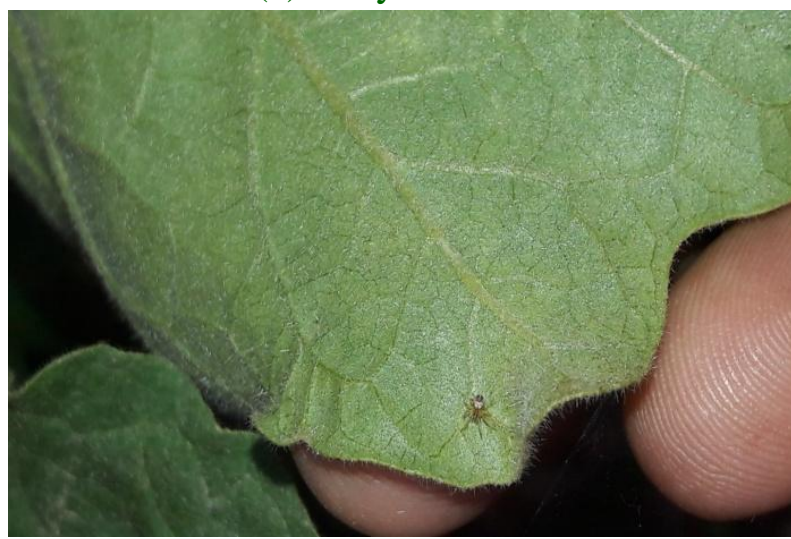

(e) Bark sac spider (d) Dragonfly

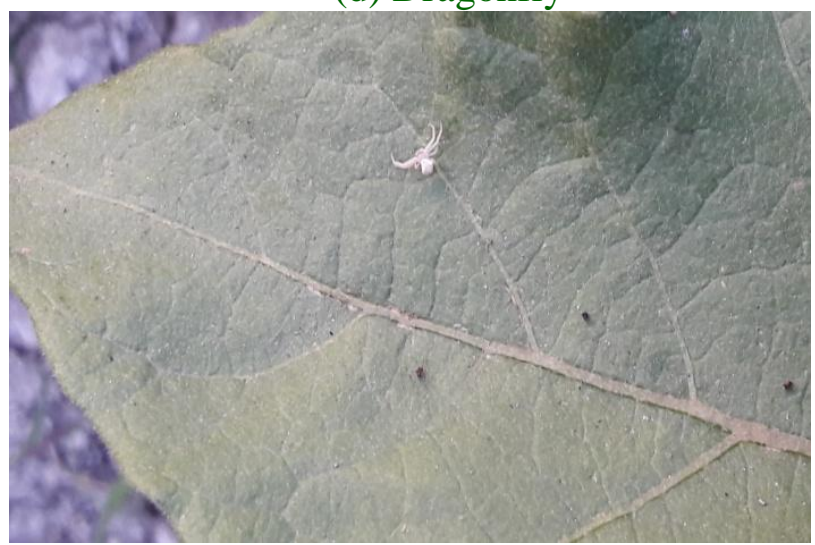

(f) White banded crab spider

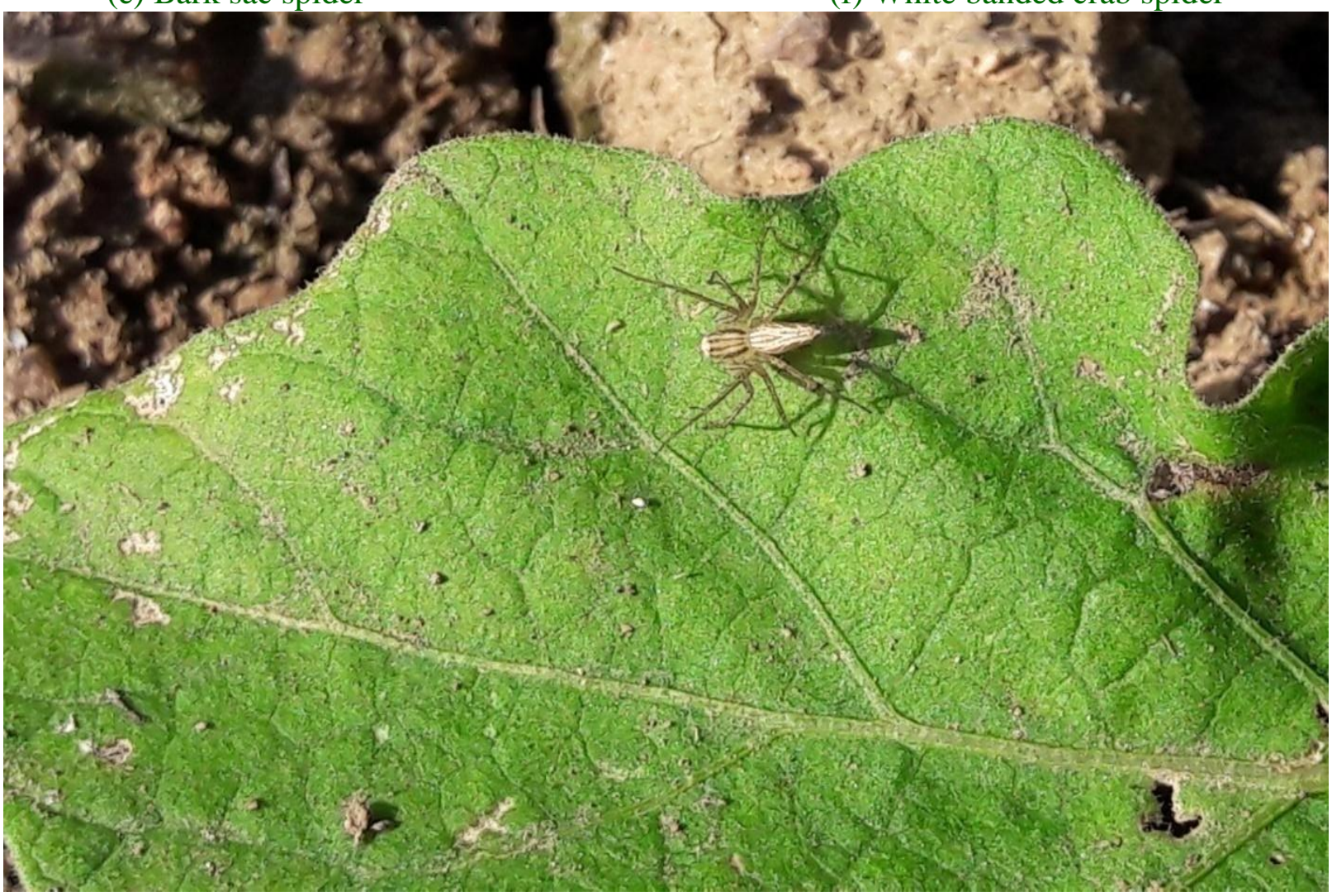

(g) Striped lynx spider 
Plate.3 Incidence of insect pests in brinjal crop in Rewa district during Kharif \& Rabi 2016-2017

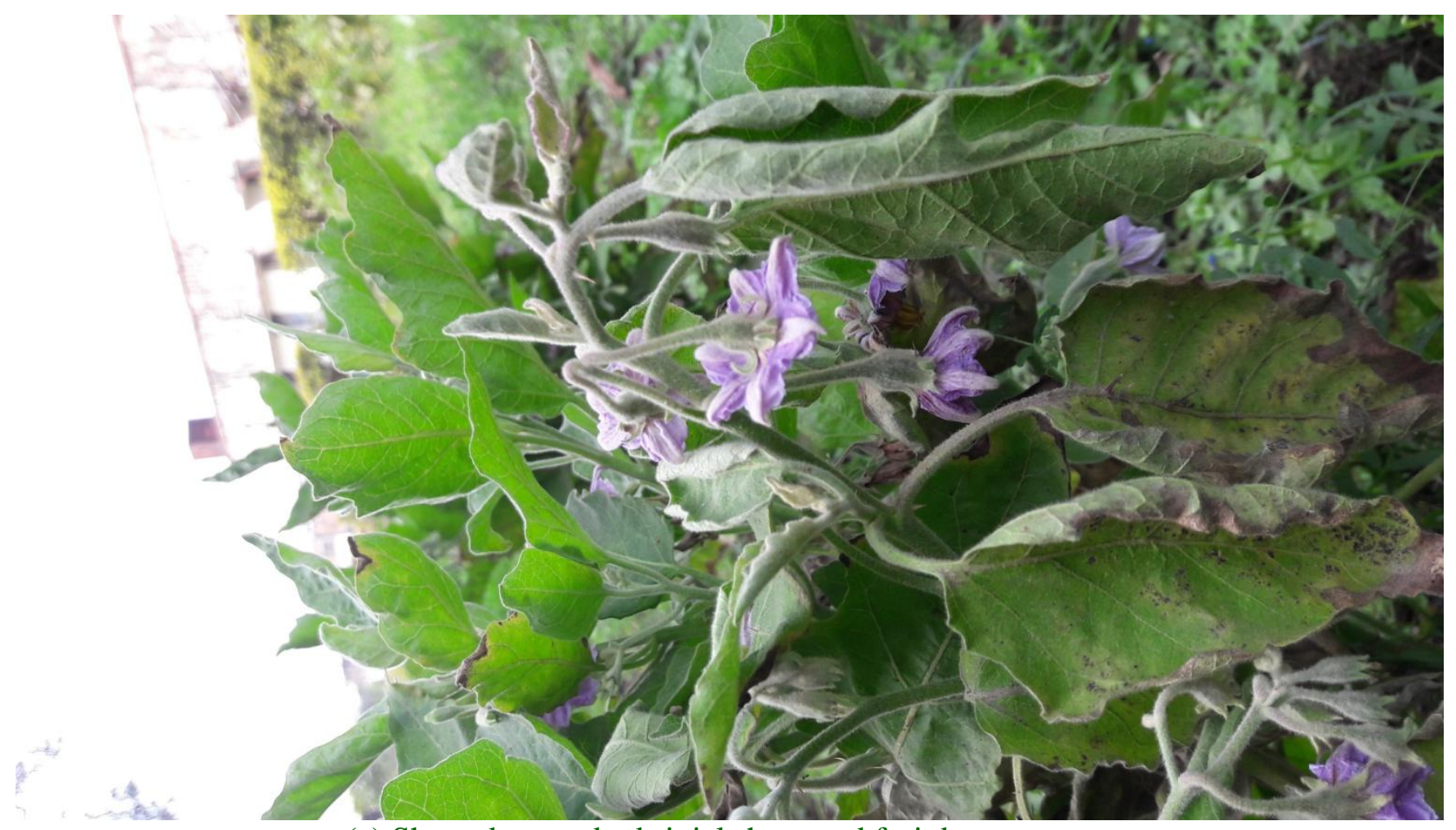

(a) Shoot damage by brinjal shoot and fruit borer

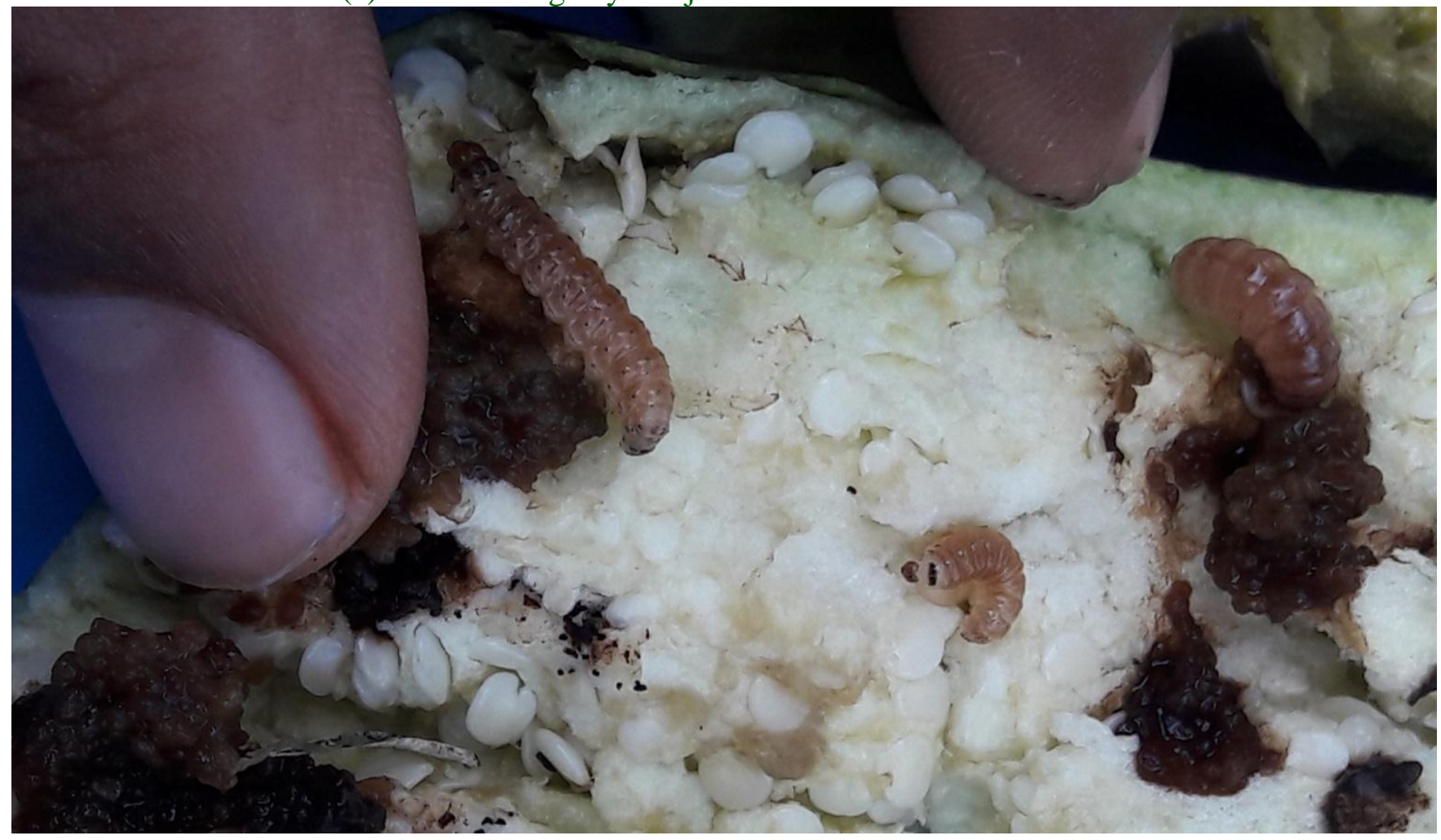

(b) Fruit damage by brinjal shoot and fruit borer 
Fig.4 Incidence of insect pests and natural enemies in brinjal crop in Rewa district during Kharif \& Rabi 2016-2017

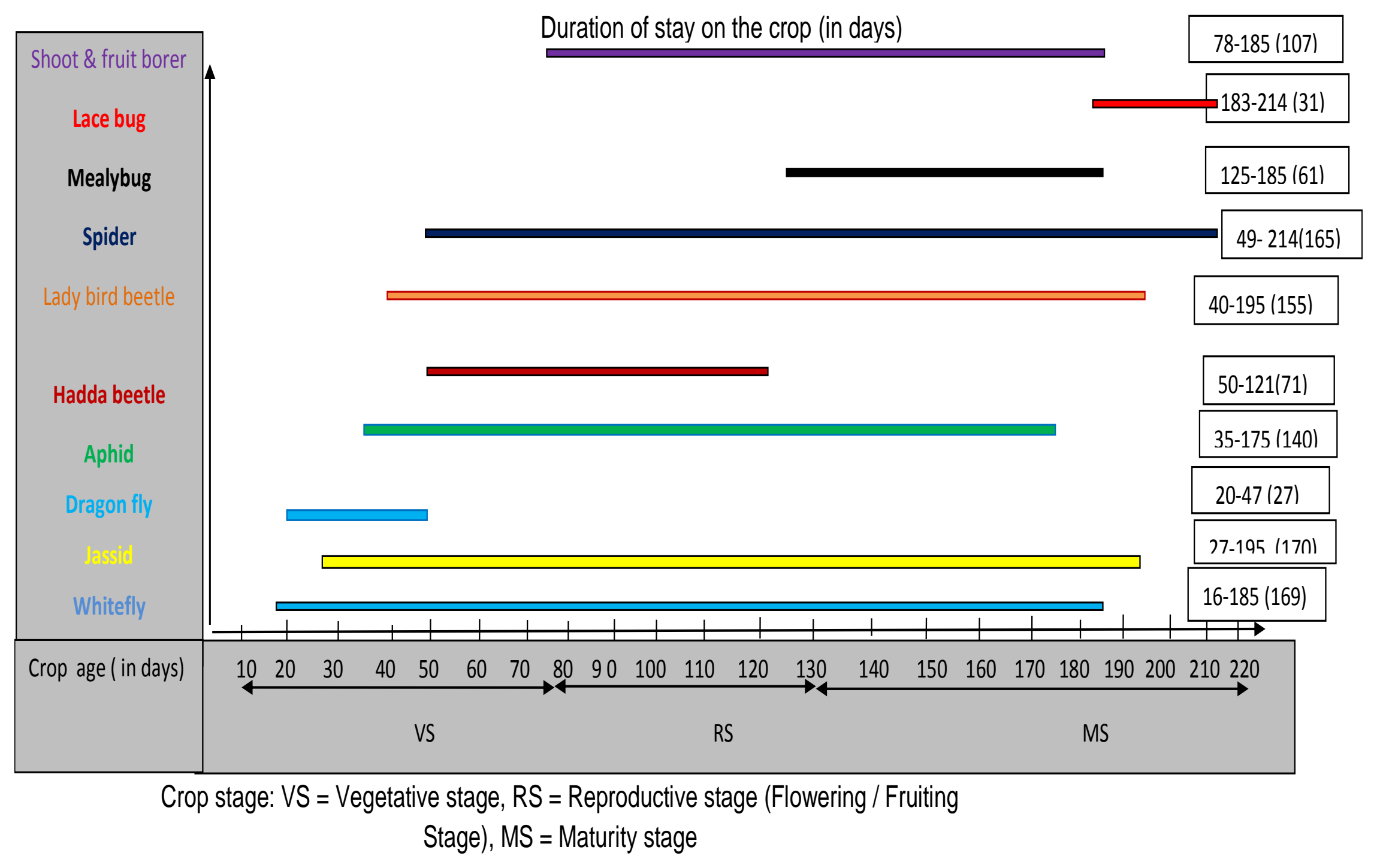


Table.1 Incidence of insect pests and natural enemies in brinjal crop in Rewa district during Kharif \& Rabi 2016-2017

\begin{tabular}{|c|c|c|c|c|c|c|c|}
\hline $\begin{array}{l}\text { S. } \\
\text { No. }\end{array}$ & $\begin{array}{l}\text { Common name of } \\
\text { insect pests/ } \\
\text { Natural enemy }\end{array}$ & Scientific name & Order & Family & $\begin{array}{l}\text { Crop } \\
\text { age } \\
\text { (DAT) }\end{array}$ & $\begin{array}{l}\text { Period of } \\
\text { activity }\end{array}$ & $\begin{array}{l}\text { Crop } \\
\text { stage }\end{array}$ \\
\hline 1. & Whitefly & $\begin{array}{l}\text { Bemisia tabaci } \\
\text { (Genn.) }\end{array}$ & Hemiptera & Aleyrodidae & 16 & $\begin{array}{l}2^{\text {nd }} \text { October to } \\
20^{\text {th }} \text { March }\end{array}$ & VS \\
\hline 2. & Jassid & $\begin{array}{l}\text { Amrasca biguttula } \\
\text { biguttula (Ishida) }\end{array}$ & Hemiptera & Cicadellidae & 27 & $\begin{array}{l}13^{\text {th }} \text { October } \\
\text { to } 30^{\text {th }} \text { March }\end{array}$ & VS \\
\hline 3. & Aphid & $\begin{array}{l}\text { Myzus persicae } \\
\text { (Sulzer) }\end{array}$ & Hemiptera & Aphididae & 35 & $\begin{array}{l}21^{\text {st }} \text { October } \\
\text { to } 10^{\text {th }} \text { March }\end{array}$ & VS \\
\hline 4. & Hadda beetles & $\begin{array}{l}\text { Epilachna } \\
\text { vigintioctopunctata }\end{array}$ & Coleoptera & Coccinellidae & 50 & $\begin{array}{c}5^{\text {th }} \text { November } \\
\text { to } 15^{\text {th }} \\
\text { January }\end{array}$ & VS \\
\hline 5. & Mealybug & $\begin{array}{l}\text { Coccidohystrix } \\
\text { insolita (Green) }\end{array}$ & Hemiptera & Pseudococcidae & 125 & $\begin{array}{l}19^{\text {th }} \text { January } \\
\text { to } 20^{\text {th }} \text { March }\end{array}$ & FFS \\
\hline 6. & Lace bug & $\begin{array}{l}\text { Urentius sentis } \\
\text { (Distant) }\end{array}$ & Hemiptera & Tingidae & 183 & $\begin{array}{c}18^{\text {th }} \text { March to } \\
14^{\text {th }} \text { April }\end{array}$ & FFS \\
\hline 7. & $\begin{array}{l}\text { Shoot and Fruit } \\
\text { borer }\end{array}$ & $\begin{array}{l}\text { Leucinodes orbonalis } \\
\text { (Guenn.) }\end{array}$ & Lepidoptera & Pyralidae & 84 & $\begin{array}{l}3^{\text {rd }} \text { December } \\
\text { to } 20^{\text {th }} \text { March }\end{array}$ & VS/FFS \\
\hline \multicolumn{8}{|c|}{ (Natural enemies) } \\
\hline 8. & Lady bird beetle & $\begin{array}{l}\text { Cheliomenes } \\
\text { sexmaculata } \\
\text { Fabricius. }\end{array}$ & Coleoptera & Coccinellidae & 40 & $\begin{array}{l}26^{\text {th }} \text { October } \\
\text { to } 30^{\text {th }} \text { March }\end{array}$ & VS/FFS \\
\hline 9. & Dagon fly & Crocothemis servilia & Odonata & Libellulidae & 20 & $\begin{array}{l}6^{\text {th }} \text { October to } \\
2^{\text {nd }} \text { November }\end{array}$ & VS/FFS \\
\hline \multirow{4}{*}{10} & Spiders & & & & & & \\
\hline & Striped lynx spider & Oxyopes salticus & Araneae & Oxyopidae & \multirow{3}{*}{49} & \multirow{3}{*}{$\begin{array}{l}25^{\text {th }} \text { October } \\
\text { to } 14^{\text {th }} \text { April }\end{array}$} & \multirow{3}{*}{ VS/FFS } \\
\hline & $\begin{array}{l}\text { White banded crab } \\
\text { spider }\end{array}$ & $\begin{array}{l}\text { Misumenoids } \\
\text { formosipes }\end{array}$ & Araneae & Thomisidae & & & \\
\hline & Bark sac spider & Clubiona spp. & Araneae & Clubionidae & & & \\
\hline
\end{tabular}




\section{Natural enemies}

Among the natural enemies of the insect pests of the brinjal crop, lady bird beetle, dragonfly and many species of spiders were seen in the crop ecosystem from October 2016 to April 2017.

\section{Lady bird beetle}

Among the natural enemies the occurrence of lady bird beetle was seen when it was 43 days old after transplanting and thereafter remained active upto the end of $30^{\text {th }}$ March 2017.

\section{Spiders}

Among the natural enemies sufficient number of various species of spiders namely, striped lynx spider, white banded crab spider and bark sac spider were seen in the crop from 49 days after transplanting and found active throughout the experimentation period i.e. $2^{\text {nd }}$ week of April.

\section{Dragonfly}

The Dragonfly was seen in abundance from on 20 days after transplanting and remained active therein up to the end of $5^{\text {th }}$ week of October 2016.

Thus, overall 7 insect pests (5 sap feeder, one foliage feeder and one borer) and three natural enemies were recorded on the brinjal crop, during Kharif \& Rabi 2016-2017 from the agro-climatic condition of Rewa district.

Among the insect pests; five species were noted from Hemiptera, one species from Coleoptera and one species from Lepidoptera order. While among the natural enemies Ladybird beetle and Dragonfly were noted from Coleoptera and Odonata order respectively. In addition to the spiders which belong to order the Araneae.
Incidence of these insect pests and natural enemies on brinjal has also been reported by various workers, Gangwar and Singh (2014) while Latif et al., (2009) reported twenty species of harmful arthropods belonging to 17 families, and 6 orders. In the present study the aphid species recorded in the crop were Myzus persicae sulzer but Elanchezhyan et al., (2008) and Kadam et al., (2006) reported Aphis gossypii species in the brinjal crop.

\section{References}

Anonymous 1999. Guide to Agriculture Dr. Panjabrao Deshmukh Krishi Vidyapeeth, Akola pp-139.

Deole S. 2015. Population dynamics of major insect pests of brinjal crop in summer season. Journal of Hill Agriculture 6(2): 180-183.

Elanchezhyan K, Baskaran RKM and Rajavel DS. 2008. Influence of intercrops on incidence of major pests of brinjal and their natural enemies. Annals of Plant Protection Sciences 16(1): 87-91.

Gangwar RK and Singh DV. 2014. Study on insect pest succession of brinjal crop ecosystem in Western Region of Uttar Pradesh. Indian Journal of Biology, Agriculture and Healthcare 4(17): 116119.

Kadam JR, Bhosale UD and Chavan AP. 2006. Influence of insecticidal treatment sequences on population of Leucinodes orbonalis Guen. and its predators. Journal of Maharashtra agriculture University 31(3): 379-382.

Latif MA, Rahman MM, Alam MZ. 2009. Efficacy of nine insecticides against shoot and fruit borer, Leucinodes orbonalis Guenee (Lepidoptera: Pyralidae) in eggplant. Journal of pest science 83: 391-397.

NHB website; (2014) and for India data Indian Horticulture Database, pp- 133. 
Shukla A and Khatri SN. 2010. Incidence and borer Leucinodes orbonalis Guenee. abundance of brinjal shoot and fruit The Bioscan 5(2): 305-308.

\section{How to cite this article:}

Sachin Kumar Jaiswal, M.R. Dhingra, Akhilesh Kumar, Harishankar Bagchi and Umashankar Kaushik. 2018. Incidence of Insect Pest in Brinjal under Agro-Climatic Condition of Rewa District, Madhya Pradesh, India. Int.J.Curr.Microbiol.App.Sci. 7(06): 1241-1249. doi: https://doi.org/10.20546/ijcmas.2018.706.146 